REVIEW ARTICLE

\title{
PATHOPHYSIOLOGY AND MANAGEMENT OF INHALATION TRAUMA IN BURN PATIENTS: LITERATURE REVIEW
}

\author{
Agus Roy Rusly Hariantana Hamid ${ }^{1}$, I Gusti Putu Hendra Sanjaya ${ }^{1}$, Gede Wara Samsarga ${ }^{1^{*}}$, \& Ni \\ Made Ratih Purnama Dewi ${ }^{2}$
}

1. Division of Plastic Surgery, Faculty of Medicine Udayana University, Denpasar, Indonesia 2. Faculty of Medicine Udayana University, Denpasar, Indonesia

\begin{abstract}
Introduction: Inhalational trauma is a significant cause of morbidity and mortality rates in burn patients. The high mortality rate for a burn with inhalation trauma requires a good understanding of the pathophysiology to provide comprehensive treatment.

Method: Electronic literature searching of the MEDLINE (PubMed), Cochrane, and Google Scholar databases were conducted. Studies regarding inhalation trauma pathophysiology and its management that were eligible and available were chosen and used in this paper.

Result Inhalational trauma pathophysiology can be divided into three, namely damage to the upper respiratory tract, lower respiratory tract, and systemic toxicity. Management can be divided based on post-exposure early management (0-72 hours) and advanced management (3-21 days).

Conclusion: At present, the management of inhalation trauma is still moderately supportive. Further research based on inhalation trauma pathophysiology is still needed for effective management so that later it can reduce the morbidity and mortality rates.
\end{abstract}

Keywords: Inhalation Trauma; Burn; Pathophysiology; Management

Latar Belakang: Trauma inhalasi merupakan penyebab signifikan dari morbiditas dan mortalitas pada pasien dengan luka bakar. Tingginya angka mortalitas pada pasien luka bakar dengan trauma inhalasi membutuhkan pemahaman yang baik terkait patofisiologi trauma inhalasi sehingga mampu memberikan penanganan yang efektif pada pasien luka bakar dengan trauma inhalasi

Metodologi: Pencarian secara elektronik dilakukan pada data MEDLINE (PubMed), Cochrane, and Google Scholar terkait patofisiologi dan manajemen dari trauma inhalasi.

Hasil: Patofisiologi dari trauma inhalasi dapat dibedakan menjadi tiga yaitu saluran pernafasan atas, saluran pernafasan bawah dan toksisitas sistemik. Manajemen trauma inhalasi dapat dibedakan menurut waktu menjadi manajemen dini paska paparan (0-72 jam) dan manajemen lanjut paska paparan (3-21 hari).

Kesimpulan: Saat ini penanganan trauma inhalasi pada luka bakar masih bersifat suportif. Penelitian lebih lanjut terkait patofisiologi luka bakar penting dilakukan untuk nantinya mampu mengetahui manajemen yang tepat sehingga menurunkan angka morbiditas dan mortalitas pasien luka bakar dengan trauma inhalasi.

Kata Kunci: Inhalation Trauma; Burn; Pathophysiology; Management

\section{Conflicts of Interest Statement:}

The author(s) listed in this manuscript declare the absence of any conflict of interest on the subject matter or materials discussed. 


\section{INTRODUCTION}

Burn cases are increasing every year, with high morbidity and mortality rates, especially in a developing country ${ }^{1}$. An estimated 7.1 million cases of burns occur and result in 265,000 deaths each year.1 According to data from the Ministry of Health of Indonesia in 2014, burns ranked 6th of all accident cases and resulted in 195,000 deaths annually ${ }^{1}$.

Major burns affect all organ systems and result in changes and physiological responses that trigger systemic catabolism throughout the body and increase morbidity and mortality ${ }^{2}$. The development of burn management, nutrition, wound closure, and antimicrobial therapy can increase patients' life expectancy with significant burns, but if burns are accompanied by inhalation trauma, morbidity and mortality rates are still significantly high².

Inhalation trauma occurs in more than $30 \%$ of burns cases; where every year in the United States, there are 23,000 cases of inhalation trauma and result in 5,000-10,000 deaths ${ }^{3}$. The presence of inhalational trauma in burn cases increases $20 \%$ mortality in burns and is an independent predictor of mortality in burns and decreases survival rate in patients with the same age and extent of burns without inhalation trauma 4 . Inhalation trauma results in an increase in the need for fluid resuscitation and results in respiratory organ complications in $73 \%$ of cases and triggers Acute Respiratory Syndrome (ARDS) in $20 \%$ of cases 5 .

The high mortality rate for a burn with inhalation trauma requires a good understanding of its pathophysiology, so comprehensive treatment for burn patients with inhalational trauma can be provided.

\section{METHOD}

We conducted electronic literature searching of the MEDLINE (PubMed), Cochrane, and Google Scholar databases using search terms "inhalation trauma," "pathophysiology," "management." Studies that were eligible and were available are chosen and used in this paper.

\section{RESULTS}

\section{PATHOPHYSIOLOGY ON INHALATION TRAUMA}

Inhalation trauma is a term used to describe damage to the respiratory tract mucosa due to exposure to irritants that cause clinical manifestations of respiratory distress. ${ }^{6}$ According to the anatomic location, inhalational trauma can be divided into three, namely damage to the upper respiratory tract, lower respiratory tract, and systemic toxicity. ${ }^{7}$

\section{Inhalation Trauma in the Upper Respiratory Tract}

Pathophysiology of inhalational trauma to the upper respiratory tract caused by the same microvascular changes occurs in burns in other parts of the body. The heat causes denaturation of proteins, which in turn activates the complement, which results in the release of histamine. Histamine triggers xanthine oxidase formation, an enzyme that functions in the breakdown of purines into gout. During this conversion process, Reactive Oxygen Species (ROS) are formed and joined with Nitric Oxide (NO) in the endothelium to form Reactive Nitrogen Species (RNS). ROS and RNS result in an increase in endothelium permeability to the protein resulting in airway edema. ${ }^{5}$ Besides, eicosanoids and IL-8 also form post-trauma and cause migration of polymorphonuclear cells, increasing the inflammatory process and ROS formation. Inflammation and irritants activate pulmonary Cfiber receptors and increase NO production, which in turn aggravates airway edema. ${ }^{5}$

Management of burn resuscitation is generally done by administering high amounts of crystalloid fluids, reducing oncotic plasma pressure. ${ }^{3,5}$ This decrease affects the decrease in oncotic pressure gradient in the microcirculation and increases the filtration coefficient, resulting in damage to microvascular function, which will ultimately aggravate massive edema in the upper airway.

It increased mucous production in obstructing the distal respiratory tract and atelectasis, which ultimately disrupts the gas exchange process. ${ }^{9,10}$ The time needed for maximal upper respiratory tract edema can reach 18 hours or more. ${ }^{9}$ Edema generally decreases within 4-5 days after the inhalation trauma. ${ }^{11}$ 


\section{Inhalation Trauma in the Lower Respiratory} Tract

\section{Inhalation Trauma to The Tracheobronchial System}

The chemical effects of inhalants usually cause trauma to the tracheobronchial system. ${ }^{3}$ In inhalation trauma, inhalation smoke stimulates nerves in the respiratory tract to produce neuropeptides, which are potent bronchoconstrictor, which causes increased blood flow and changes in capillary permeability. ${ }^{6}$

Under physiological conditions, the respiratory mucosa produces neutral endopeptidase, which neutralizes the toxin agent. $^{3}$ In inhalation trauma, cellular damage occurs, which results in the inactivation of the neutralization effect. ${ }^{9}$ This decrease in endopeptidase results in an increase in neuropeptide response activity, namely an increase in Bronchoconstriction Substance $P$ and Neurokinin Activity (NKA).6 This mechanism is persistent and sometimes permanently increases airway irritability, bronchospasm, and capillary permeability. ${ }^{6}$

Neuropeptides also attract and activate neutrophils, which result in the production of ROS. ${ }^{3}$ Simultaneously, neuropeptides upregulate the neuronal activity of NO synthase (nNOS, NOS-1). NOS catalyzes the production of $\mathrm{NO}$ and L-citrulline from the amino acid L-arginine through the five electron reduction complex reaction. ${ }^{9}$

Nearly all ROS and RNS can interact with proteins, DNA or fat by oxidation, nitration, and nitrosylation, which cause inactivation of essential enzymes such as glyceraldehydes-3phosphate dehydrogenase enzymes or cause single-strand damage to DNA. ${ }^{3}$ DNA damage triggers the formation of poly (ADP ribose) polymerase (PARP). This nuclear enzyme is essential in DNA repair. ${ }^{12}$ PARP activation is induced by $\mathrm{NO}$ and its toxic products, such as RNS. Although PARP's physiological effects are beneficial, PARP activation depletes cellular ATP by producing ADP, resulting in dysfunction and apoptosis. 9,12 Also, PARP activates nuclear factor кB (NF-KB), increasing IL-8 production and causing attraction and activation of PMN cells and ultimately increasing ROS production. NF$\mathrm{\kappa B}$ also stimulates the formation of iNOS, thereby accelerating the production of NO. ${ }^{9} \mathrm{NO}$, and ROS react to form RNS and cause DNA damage and activation of PARP so that the circle of positive feedback continues to repeat itself. ${ }^{9}$

Bronchial epithelial damage could result in the production of transudates with high protein content. ${ }^{9,13}$ This secretion forms a foam in the initial response and, over time, solidifies and forms obstructive material that obstructs the lower respiratory tract. ${ }^{9}$ Research shows a 10 -fold increase in bronchial circulation in 20 minutes after inhalational trauma. ${ }^{14}$ Besides, research also shows a 6-fold increase in transvascular influx in inhalation trauma. ${ }^{14}$ Both of these result in respiratory tract edema.

\section{Inhalation Trauma in Lung Parenchyma}

Alveolar damage is characterized by alveolar collapse and atelectasis caused by an increase in transvascular fluid influx, lack of surfactants, and decreased pulmonary vasoconstrictive response due to hypoxia, ultimately results in oxygenation disruption. ${ }^{9}$

Activated neutrophils play an essential role in the pathogenesis of inhalational trauma. Neutrophils initiate and continuously produce ROS and secrete proteases such as elastase. ${ }^{9}$ Also, activated neutrophils in the bronchial circulation move towards the pulmonary microvascular. Activated neutrophils have a rigid consistency due to the effect of F-actin activation so that they are unable to penetrate the pulmonary capillaries. Activated neutrophils attach to the alveolar capillaries via L-selectin, which results in indirect damage due to proteases and ROS production. Studies by Efimova et al. in sheep show ligation of the bronchial arteries reduces lung parenchymal damage due to inhalational trauma. 15,16

\section{Systemic Toxicity in Inhalation Trauma}

The direct systemic effect of inhalation trauma is caused by inhalation of toxic gases originating from the combustion of organic and inorganic substances. ${ }^{3}$ Gases that have high morbidity and mortality rates are toxicity due to carbon monoxide and cyanide.

\section{Carbon Monoxide (CO)}

$\mathrm{CO}$ is an odorless, colored gas with an affinity for Hemoglobin 200 times higher than oxygen. ${ }^{3}$ Oxygen delivery to organs is reduced due to a leftward shift of the oxygen hemoglobin dissociation curve, thereby reducing oxygen availability to the tissues. ${ }^{9}$ 
Clinical symptoms that arise depend on $\mathrm{CO}$ levels in the blood, duration of exposure, and the presence of premorbid patients. ${ }^{3}$ Clinical symptoms that arise from intoxication can be neurological and cardiovascular manifestations. Neurological manifestations such as headaches, confusion, and collapse can occur when $\mathrm{COHb}$ levels are 40-50\%.3 Unconscious symptoms, intermittent seizures, and respiratory failure can occur when $\mathrm{COHB}$ levels exceed $60 \%{ }^{3}$ Cardiovascular manifestations that can arise are tachycardia, increased cardiac output, dysrhythmias, myocardial ischemia, and hypotension depending on the severity of $\mathrm{CO}$ intoxication. 3,9

\section{Hydrogen Cyanide}

Cyanide is a normal metabolite in the human body with $0.3 \mathrm{mg} / 1 \mathrm{in}$ non-smokers and $0.5 \mathrm{mg}$ / 1 in smokers. ${ }^{3}$ Cyanide in the blood is fatal if the levels exceed 1-3 to $5 \mathrm{mg} / 1 .{ }^{17}$ All cells, especially the liver, can convert cyanide to thiocyanate, which is ultimately excreted in urine with the help of the rhodanese enzyme. In large amounts of cyanide, this excretion system can be disrupted, especially in burns and trauma patients who tend to be hypovolemic toxicity of cyanide-based on hypoxic conditions due to reversible inhibition of cytochrome $\mathrm{C}$ oxidase, which is the terminal oxidase of the oxidation chain. ${ }^{9}$ Hydrogen cyanide combines with Fe ions in cytochrome a3 oxidase in mitochondria with high affinity by altering the structure of enzymes resulting in anaerobic metabolism, ultimately increasing lactate levels and reduces oxygen consumption. Hydrogen cyanide toxicity will cause the central nervous system, respiratory and cardiovascular dysfunction due to inhibition of oxidative phosphorylation, which depends on the inhalation of cyanide. ${ }^{3}$

\section{MANAGEMENT OF INHALATION TRAUMA}

In general, there is no specific treatment for inhalation trauma, and the treatment consists of supportive modalities. Specific treatment is needed if systemic toxicity is proven in patients such as $\mathrm{CO}$ poisoning or $\mathrm{HCN}$ poisoning. According to time, handling of inhalation trauma can be divided into early management after exposure (0-72 hours) and advanced management after exposure (3-21 days). ${ }^{18}$

\section{Post-exposure Early Management (0-72 hours)}

A thorough history and physical examination can identify patients at risk of inhalational trauma, and patients with respiratory function insufficiency and other indications requiring early intervention. ${ }^{3}$ Airway evaluation is critical to recognize signs of rapid intubation or prophylactic intubation in patients with severe burns. Early hypoxemia due to disruption of gas exchange in inhalation trauma indicates immediate intubation in the patient. ${ }^{3}$ In patients without signs of inhalation trauma, burns above $40 \%$ is recommended for intubation because of the risk of hemodynamic instability. ${ }^{19}$ Patients with the risk of respiratory obstruction due to edema is also an indication of intubation. In some patients with facial and neck burns or hot steam inhalation, early intubation can be considered. The American Burn Association also recommends rapid intubation in patients at risk of airway occlusion. ${ }^{3}$

A good history and physical examination can identify patients with significant respiratory distress or other indications that require immediate intubation. In patients at risk of inhalation trauma but only showing signs of mild distress, spirometry, or bronchoscopy can be used to identify which patients are in a condition of airway obstruction that is threatening and beneficial if early prophylactic intubation is performed..$^{18,20}$ It should be emphasized that the anatomic changes seen with bronchoscopy precede gas exchange disorders and radiological changes. ${ }^{21}$ In patients who do not require early intubation, measures can be observed and repeated evaluations. If airway patency is not disturbed, especially in burns with an area of less than $20 \%$, the elevation of the head in bed, air humidification, and close monitoring is adequate. ${ }^{18}$

In inhalation trauma in the presence of burns, there is an increase in fluid requirements for resuscitation. ${ }^{3}$ In burns with severe inhalation trauma, fluid requirements within 24 hours can be $30 \%$ higher than the fluid requirements calculated according to the Parkland resuscitation formula of $4 \mathrm{ml} / \mathrm{kg} /$ total body surface area (TBSA).22 The adequacy of fluid resuscitation in burns with inhalation trauma can be measured by urine production of 0.5 $\mathrm{ml} / \mathrm{kg} /$ hour (30-60 ml/hour) in adults and 1 $\mathrm{ml} / \mathrm{kg} /$ hour in children. 
The presence of inhalational trauma is often intuitively seen as an indication to restrict fluid to prevent pulmonary edema. Fluid restriction turns out to worsen leakage in the pulmonary capillaries and increase the buildup of lymph fluid in the lungs in studies conducted in sheep with burns and inhalation trauma. ${ }^{23}$ Although it is essential to avoid fluid overloading in inhalational trauma, inadequate fluid resuscitation can worsen pulmonary damage in patients with inhalation trauma.22,23 The combination of burns with inhalation trauma makes it difficult to balance the volume of fluid sufficiently and not excessively so that it requires a more in-depth evaluation of the adequacy of the fluid given.

Another complication from inhalational trauma and requires immediate treatment is carbon monoxide (CO) and cyanide poisoning. Intoxication should be considered in all patients who have a history of exposure to smoke in a confined space. ${ }^{3}$ A definitive diagnosis requires examination of $\mathrm{COHb}$ levels where conventional pulse oximetry cannot detect oxyhemoglobin with $\mathrm{COHb}$. Increased oxygen partial pressure can accelerate elimination from CO. Oxygen supplementation with a facemask is usually adequate, but in severe cases ( $\mathrm{COHb}>>15-20 \%)$, $100 \%$ oxygen should be given via endotracheal tube. ${ }^{3}$ Hyperbaric therapy is said to be used in CO poisoning, but there is no clear consensus on indications, treatment parameters, and clinical benefits. $^{3}$

Cyanide causes cellular anoxia by binding to the mitochondrial cytochrome and preventing intracellular oxygen utilization. ${ }^{18}$ Providing additional oxygen can result in non-enzymatic oxidation of the reduced cytochrome and shift cytochrome oxidase and increase the effect of the given antidote. ${ }^{3}$ Some agents are known to bind directly to cyanide. Dicobalt edetate $(20 \mathrm{~mL}$ with a concentration of $15 \%$ in adults or $0.3-0.5 \mathrm{~mL} / \mathrm{kg}$ with a concentration of $15 \%$ in pediatric patients) has an immediate effect but has a risk of toxicity. Hydroxycobalamin administration (adults 5-10 g or in children $70 \mathrm{mg} / \mathrm{kg}$ ) is a precursor of vitamin B12 and is relatively safe to use with minimal side effects.9 Sulfur donors such as sodium thiosulfate (adults $25 \mathrm{~mL}$ with a concentration of $50 \%$ or in children) children $1.65 \mathrm{~mL} / \mathrm{kg}$ with a concentration of $25 \%$ solution) increases the body's enzymatic conversion from cyanide to thiocyanide, thereby reducing toxicity and increasing urine elimination. 3,9

\section{Advanced Management Post-exposure (3-21} days).

Bronchial hygiene therapy is a term used to describe several modalities used to cleanse the respiratory tract from secretions and debris. ${ }^{3}$ These measures consist of cough induction, chest physiotherapy, early ambulation, airway suctioning, therapeutic bronchoscopy, and pharmacological agents. These actions are proven to reduce secretions that are difficult to issue in the airway after inhalational trauma.

Cough induction functions to free the airway from excessive mucus production and fibrin cast in the respiratory tract. In patients with inhalational trauma, the coughing mechanism is often disrupted, requiring actions to induce coughing. ${ }^{3}$ One step that can be done is to use a three cough technique, where the patient is asked for a small breath and a small cough, followed by a big breath and a cough that is bigger and ends with a deep breath and a hard cough. This technique is useful in patients with postoperative pain complaints. ${ }^{3}$ Coughing and breathing exercises are done every 2 hours to be able to facilitate secretions. ${ }^{3}$

Chest physiotherapy is done by adjusting the position and chest percussion. Positioning by tilting the patient to a different side every 2 hours shows the benefits of mobilizing secretions in the bronchus. ${ }^{3}$ Chest percussion is performed by clasping hands and gently tapping the chest. Incised areas, skin grafts, and bone protrusions should be avoided when performing percussion.

Early ambulation is another effective action that can prevent complications in the respiratory tract. Patients are routinely assisted in learning to sit five days after surgery. With effective use of analgesics, patients with continuous ventilation support to be taught to wake up and learn to sit. ${ }^{3}$ Airway suctioning is one method to clean the airway. Nasotracheal suctioning aims to clear the accumulation of secretions and foreign bodies that cannot be removed by a spontaneous cough or other non-invasive procedures. The patient is in the Fowler position, and the suction catheter is slowly inserted through the nose toward the larynx. During inspiration, a catheter is inserted into the trachea. After the vocal cords have passed, some deep breathing is permitted in the patient, and the patient is reoxygenated. Patients 
should not be suctioned for more than 15 seconds without reoxygenation. ${ }^{3}$

The use of bronchodilators is often beneficial in inhalational trauma. Damage due to inhalational trauma to the lower respiratory tract often results in chemical tracheobronchitis, which results in wheezing and bronchospasm. This usually occurs in patients who have premorbid with reactive airway diseases such as asthma. ${ }^{3}$ Inhalant sympathomimetic agents are useful in causing bronchial muscle relaxation and stimulating mucociliary clearance. Sympathomimetic bronchodilators that can be given are albuterol and epinephrine.

In addition to the inhalant sympathomimetic agent, acetylcysteine is also a potent mucolytic agent in treating the respiratory tract. Acetylcysteine contains a thiol group that can release mucous disulfide bonds that provide the stability of mucoprotein molecules in mucus so that it is the most mucolytic agent. ${ }^{9}$

Heparin in the form of aerosols used in many centers can reduce cast formation in the bronchus by decreasing fibrin formation in exudates. ${ }^{3}$ Giving heparin in the form of aerosol does not result in systemic coagulation. In studies conducted in children, the combination of heparin in aerosol and acetylcysteine forms can reduce reintubation rates, the incidence of atelectasis, and mortality due to inhalation trauma. ${ }^{24}$ The recommended standard therapy for inhalation trauma is 5000-10000 units of heparin and $3 \mathrm{ml}$ of $0.9 \% \mathrm{NaCl}$, which is written every 4 hours, surrounded by $3-5 \mathrm{ml}$ of $20 \%$ acetylcysteine for seven days. This ensures that patients get aerosol therapy every 2 hours. ${ }^{3}$

Mechanical ventilation is indicated in patients with threatening or existing respiratory failure. ${ }^{3}$ Research shows that the use of minimal tidal volume (maximum $6 \mathrm{ml} / \mathrm{kg}$ ) can reduce mortality rates due to ARDS (Acute Respiratory Distress Syndrome). ${ }^{25}$ The use of mechanical ventilators must be released slowly and stopped when the patient's condition improves.

\section{CONCLUSION}

At present, the management of inhalation trauma is still supportive. Further research based on inhalation trauma pathophysiology is still needed for effective management so that later it can reduce the morbidity and mortality rates.
Correspondence regarding this article should be addressed to:

Gede Wara Samsarga, Division of Plastic Surgery, Faculty of Medicine Udayana University, Denpasar, Indonesia.

email: warasamsarga@unud.ac.id

\section{REFERENCES}

1. Wardhana A, Basuki A, Prameswara ADH, dkk. The epidemiology of burns in Indonesia's national referral burn center from 2013 to 2015. Burns Open Journal. 2017: 6773.

2. Jones SW, Williams FN, Cairns BA, Cartotto R. Inhalation Injury Pathophysiology, Diagnosis, and Treatment . Clin Plastic Surg. 2017 ; 44 : 505-511

3. Herndon, DN. Total Burn Care . 4th Ed. Edinburgh: Saunders Elsevier; 2012. Chapter 18 , The pathophysiology of inhalation injury : P 264-286

4. Walker PF, Buehner MF, Wood LA, dkk. Diagnosis and management of inhalation injury: an updated review. Critical Care. 2015 ; 19 (351) : 1-12

5. Gill P , Martin RV. Smoke Inhalation Injury. BJA Education. 2015 ; 15 (3): 143-148

6. Moenadjat, Y. Burns: Problems and Management. Jakarta: Faculty of Medicine, University of Indonesia. 2011

7. Ahuja RB, Gibran N, Greenhalgh D, dkk.. ISBI Practice Guidelines for Burn Care. Burns. 2016 ; (42) : 953-1021

8. Palmieri TL. Inhalation injury consensus conference: conclusions. J Burn Care Res. 2009; 30 (1) :209-210.

9. Rehberg S, Maybauer MO, Enkhbaatar P. Pathophysiology, management and treatment of smoke inhalation injury. Expert Rev Respir Med. 2009 3(3): 283-297

10. Albright JM, Davis CS, Bird MD, et al. The acute pulmonary inflammatory response to the graded severity of smoke inhalation injury. Crit Care Med . 2012; 40: 1113-21.

11. Saab M, Majid I. Acute pulmonary oedema following smoke inhalation. Int J Clin Pract 54:115-116, 2000.

12. Pacher P, Szabo C. Role of the peroxynitritepoly(ADP-ribose) polymerase pathway in human disease. Am J Pathol . 2008 ;173(1):213.

13. Demling RH. Smoke inhalation lung injury: an update. Eplasty 2008;8: e27 
14. Abdi S, Herndon D, McGuire J, Traber L, Traber DL. Time course of alterations in lung lymph and bronchial blood flows after inhalation injury. J Burn Care Rehabil 1990;11(6):510-515.

15. Efimova $\mathrm{O}$, Volokhov $\mathrm{AB}$, Iliaifar $S$, Hales CA. Ligation of the bronchial artery in sheep attenuates early pulmonary changes following exposure to smoke. J Appl Physiol. 2000; 88(3):888-893.

16. The Education Committee of Australia and New Zealand Burn Association (ANZBA). Emergency Management of Severe Burns. Kolegium Ilmu Bedah Indonesia. 2013

17. Parimon T, Kanne JP, Pierson DJ. Acute inhalation injury with evidence of diffuse bronchiolitis following chlorine gas exposure at a swimming pool : Case report. Respire Care 2004 ; 49(3): 291-4.

18. Sheridan, RL. Fire-Related Inhalation Injury. N Engl J Med . 2016.375 (5) ; 464- 9

19. Cancio LC. Airway management and smoke inhalation injury in the burn patient. Clin Plast Surg. 2009;36(4):555-567.

20. Dries DJ, Endorf FW. Inhalation injury: epidemiology, pathology, treatment strategies. Scandinavian Journal of Trauma, Resuscitation and Emergency Medicine. 2013 ; 21 (31) : 1-15

21. Walker PF, Buehner, MF, Wood LA. Diagnosis and management of inhalation injury: an updated review. Critical Care. 2015; 19 (351) : 1-12

22. Naver PD, Saffle JR, Warden GD (1986) Effect of inhala- tion injury on fluid resuscitation requirements after thermal injury. J Plast Reconstr Surg 78: 550

23. Herndon DN, Traber DL, Traber LD. The effect of resuscitation on inhalation injury. Surgery. 1986;100(2):248-251.

24. Desai $\mathrm{MH}$, et al. Reduction in mortality in pediatric patients with inhalation injury with aerosolized heparin/N-acetylcystine correction of acetylcystine therapy. J Burn Care Rehabil. 1998; 19(3):210-212.

25. The Acute Respiratory Distress Syndrome Network. Ventilation with lower tidal volumes as compared with traditional tidal volumes for acute lung injury and the acute respiratory distress syndrome. $N$ Engl J Med. 2000;342(18):1301-1308.
26. Shirani KZ, Pruitt Jr BA, Mason Jr AD. The influence of inhalation injury and pneumonia on burn mortality. Ann Surg. 1987;205:82-7.

27. Gupta K, Mehrotra M, Kumar P, dkk. Smoke Inhalation Injury: Etiopathogenesis, Diagnosis, and Management. Indian Journal of Critical Care Medicine. 2018 ; 22 (3) : 59-64

28. Mlcak RP, Suman OE, Herndon DN. Respiratory management of inhalation injury. Burns. 2007;33:2-13. doi: 10.1016/j.burns.2006.07.007. 